This item was submitted to Loughborough's Research Repository by the author.

Items in Figshare are protected by copyright, with all rights reserved, unless otherwise indicated.

\title{
Actions, attitudes and beliefs of occupants in managing dampness in buildings
}

PLEASE CITE THE PUBLISHED VERSION

https://doi.org/10.1108/IJBPA-06-2018-0044

\section{PUBLISHER}

(C) Emerald Publishing Limited

\section{VERSION}

AM (Accepted Manuscript)

\section{PUBLISHER STATEMENT}

This work is made available according to the conditions of the Creative Commons Attribution-NonCommercialNoDerivatives 4.0 International (CC BY-NC-ND 4.0) licence. Full details of this licence are available at: https://creativecommons.org/licenses/by-nc-nd/4.0/

\section{LICENCE}

CC BY-NC-ND 4.0

\section{REPOSITORY RECORD}

Blay, Karen B., K. Agyekum, and Alex Opoku. 2019. "Actions, Attitudes and Beliefs of Occupants in Managing Dampness in Buildings". figshare. https://hdl.handle.net/2134/34818. 


\title{
Actions, attitudes and beliefs of occupants in managing dampness in buildings
}

\section{Karen Blay ${ }^{1}$, Kofi Agyekum² \& Alex Opoku}

${ }^{1}$ School of Architecture, Building and Civil Engineering, Loughborough University, Loughborough, UK. ${ }^{2}$ Building Technology Department, Kwame Nkrumah University of Science and Technology, Ghana

3UCL Bartlett School of Construction and Project Management, University College of London.

\begin{abstract}
Dampness in buildings affects the health of occupants, structural stability and energy efficiency of buildings. Solutions to managing dampness focus on promoting the use of damp-proof construction materials, enhancing methods to avoid the introduction of moisture during construction and creating the awareness on the health effect of dampness. These solutions are incomplete without the identification of behaviours that occupants require to manage dampness. Given that dampness is characterised by the availability of a source, a route for the moisture to travel and driving force for moisture movement, the occupants can be said to play a significant role in contributing to dampness. As a result, this study seeks to examine the behaviours of occupants manifested to manage dampness in residential buildings. To achieve the aim, a qualitative research method was employed, under which interviews were carried out. Occupants in households in the northern and southern parts of England were interviewed to identify the actions, attitudes and beliefs in managing dampness. The findings revealed actions such as aeration and the use of anti-damp sprays. From the findings, dampness instilled attitudes such as anger, moodiness and unhappiness. In addition, dampness instilled cleaning habits in occupants due to the lack of comfort moulds create and the awareness of its health impact. The identification of these behaviours creates the awareness for occupants on their roles in managing dampness and how dampness affects their behaviours in addition to the health impact. This research also contributes to existing debates on dampness reduction specifically in residential buildings.
\end{abstract}

Keywords: human behaviour, actions, attitudes, belief, residential buildings, dampness-reduction

\section{Introduction}

The manifestation of dampness, which can be defined as any visible, measurable or perceived outcome of excess moisture that causes problems in buildings, such as mould, leaks or material degradation (Heseltine \& Rosen, 2009) is in three ways; rising damp, penetrating (lateral) damp, and condensation (Burkinshaw \& Parrett, 2003). Whilst rising damp is caused by the rise of groundwater through walls, 
floors and masonry via capillary action (Franzoni, 2014), penetrating (lateral damp) is caused by moisture through porous walls, degraded mortar and other building defects such as leaking pipes, missing tiles and even overflowing gutters. Condensation damp is caused through the accumulation of excessive water vapour indoors (Burberry, 2014). The negative effect of dampness on the structural stability of a building has led to diverse 'construction-focussed' management approaches during and after the construction process (example, Rock, 2017; Agyekum et al., 2017; Mendell, 2017).

Dampness reduction approaches are proactive and reactive. Within literature, proactive approaches outlined are source-specific and construction-focussed. Rising damp, which is considered the major source of dampness (Agyekum \& Ayarkwa, 2014), is mainly reduced by including damp-proof courses with varying thicknesses on walls, using efficient mortar properties (Rirsch \& Zhang, 2010), creating a physical or chemical barrier, creating a potential against the capillary potential, applying atmospheric drainage, applying a coating with controlled porosity, concealing the anomalies, and ventilating the wall base (Torres \& Freitas, 2007). Penetrating (lateral) damp is reduced by installing a tanking system and using cementitious slurry and bonding agent whilst condensation is reduced by including a moisture eliminator.

The different types of dampness are associated with varying symptoms. For instance, rising damp has symptoms such as hygroscopic salts, moisture in skirting, moisture above $1.5 \mathrm{~m}$ and dampness below $1.5 \mathrm{~m}$ (Agyekum et al., 2013). Condensation on the other hand has water droplets, moisture above $1.5 \mathrm{~m}$ and mould on ceiling and top of walls. The symptoms for penetrating (lateral) dampness include water droplets, moisture above 1.5m and mould in ceiling and top of walls (Agyekum et al., 2013).

To reactively reduce dampness, it must first be diagnosed. Whilst the four diagnostic stages for dampness include visual inspection, investigations using moisture meters/ non-destructive tests, destructive tests and assessment study (Halim et al., 2012; Burkinshaw \& Parrett, 2004), further research to consider the third parties involved, specifically the behaviours for managing dampness after diagnosis has received little focus. Given that the people factor is key to continually reducing dampness, understanding the contribution by occupants through studying their actions, attitudes and beliefs through questioning is key to ensuring successful damp-reduction. The behaviour of people is influenced by a cause which leads to an effect (Skinner, 1953; Huang et al., 2017). Theories on how dampness influences people's behaviour and how behaviours reduce dampness are underdeveloped; hence, this study seeks information from occupants in households to determine if dampness affects their behaviours. Following that, this research identifies the actions and attitudes influenced by and manifested to manage dampness to begin the debate on synergy between dampness reduction and behaviours. 
Therefore, it is argued in this paper that, existing solutions are incomplete without the consideration of the human-behavioural-factor view. Given that dampness is characterised by the availability of a source, a route for the moisture to travel and driving force for moisture movement, the research questions are; what role do occupants play in causing and reducing dampness? Specifically, what behaviours do occupants manifest to reduce dampness in residential buildings? Does dampness affect the behaviour of occupants?

This paper is presented in four parts; a review of theory of occupant behaviour and the need for further research on dampness reduction specifically on behaviours, research and data collection method, analysis of results and discussion of findings.

\section{Theory of occupant behaviour}

Behaviour is a continuous process and can only be studied if observed or reported by focussing on the cause (Skinner, 1953; Fishbeing and Ajzen, 2005). For this study, the cause influencing behaviour is dampness. The dimensions of occupant behaviour have evolved. Dating back to 1980, occupant behaviour research, which focussed on the relationship between behaviour and energy use in buildings have evolved with varying dimensions with recent examples captured in Table 1. However, fundamentally, the theory of behaviour captures three dimensions namely; actions, attitudes, belief (Ajzen 1985; Blaga, 2014). This research uses these dimensions as lenses to capture how dampness affects people's behaviours and identify the role behaviours play in reducing dampness.

\section{Table 1: Dimensions of occupant behaviours}

\begin{tabular}{lll}
\hline Author & Context & Dimensions \\
\hline Peng at al. (2012) & Energy in building & $\begin{array}{l}\text { Time related, environmental related and random } \\
\text { behaviour }\end{array}$ \\
$\begin{array}{l}\text { Hong \& Lin (2013) } \\
\text { Klein et al. (2012) }\end{array}$ & $\begin{array}{l}\text { Energy in buildings } \\
\text { Comfort management }\end{array}$ & $\begin{array}{l}\text { Austerity, standard, wasteful } \\
\text { wander, attend, teach, study, and perform }\end{array}$ \\
$\begin{array}{l}\text { Yilmaz et al. (2017) } \\
\text { Moon and Yoon (2010) }\end{array}$ & $\begin{array}{l}\text { Behaviour modelling } \\
\text { Keall et al. (2012) }\end{array}$ & $\begin{array}{l}\text { Presence, actions } \\
\end{array}$ \\
\hline
\end{tabular}

The relationship between the three-dimensional lens and dampness reduction is captured in Figure 1 below, where beliefs can be said to be convictions driven by ones' culture and values and influences attitudes. Attitude on the other hand is a position adopted towards an event with explicit expression whilst action is a display of both beliefs and attitudes (Blaga, 2014; Ajzen, 2005). 


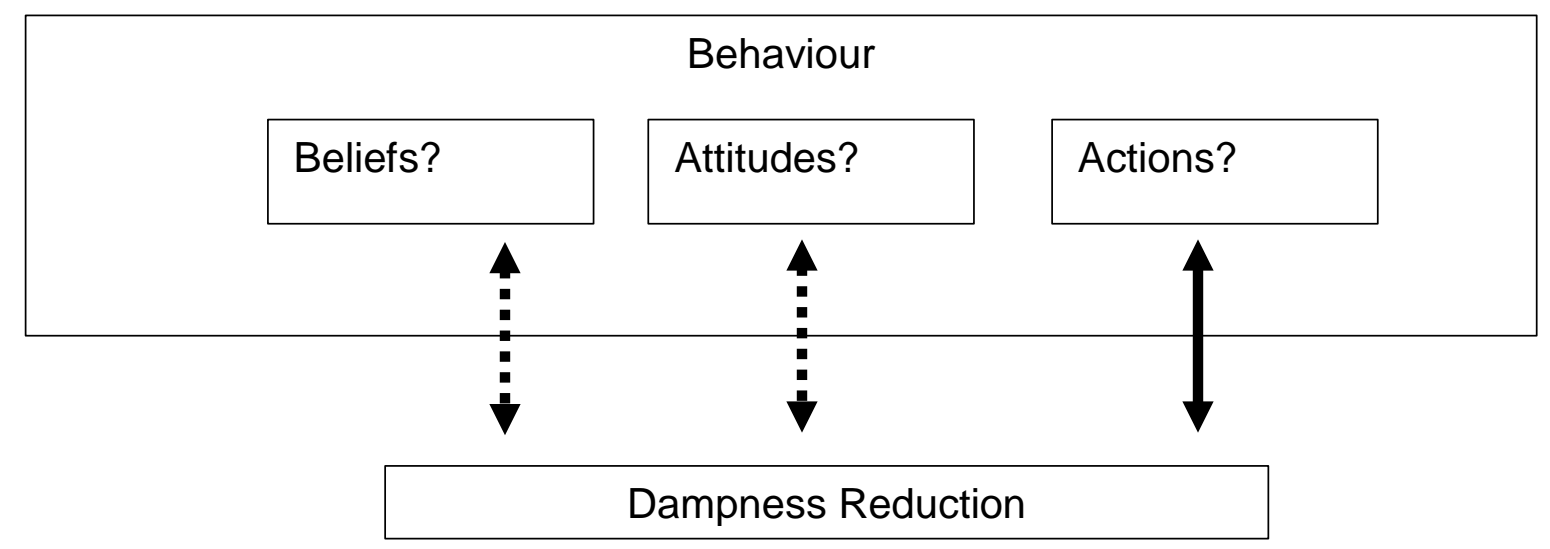

Figure 1: Conceptual framework for behaviours required for dampness reduction

From Figure 1, the observable dimension of behaviour is action which is influenced by time, environment and random occurrence (Peng at el., 2012). Thus, depending on the time of the day, actions to contribute to or reduce dampness can be said to vary whilst under environment, the weather influences occupants' behaviour as this may affect the air-quality and thus, lead to actions such as window opening or closing, timer settings and choice of thermostat set-points (Yilmaz et al., 2017).

Similarly, dampness can influence occupant behaviour and health. Whilst health risk has been largely researched (example Keall et al., 2012), the influence of dampness on behaviour and the behaviour manifested to reduce dampness has received little focus. The closest research to human participation in dampness reduction focuses on ensuring the accuracy of manuals to be followed by occupants with the help of technological tools and platforms such as; Building Information Modelling and asset management (Eastman et al., 2011), the role of females in maintaining building (Gebler, 1997) and do-it-yourselfmanuals (Watson and Shove, 2008) with minimal focus on occupant behaviour in managing the specific issue despite it being the fundamental factor.

\section{Research method}

This study examined the behaviours of occupants manifested to manage dampness in residential buildings through a qualitative study; specifically, interviews with occupants in households. Interviews 
with household occupants afforded the opportunity to identify and examine behaviours affected by and affecting dampness (Fellows \& Liu, 2008). This interactional method enabled the household occupants to reveal, describe and report (Fellows \& Liu, 2008) behaviours which were influenced by and influenced dampness. The scarcity of literature on behaviours and dampness reduction meant a semi-structured interview, which consists of questions to define an area of exploration and enables the interviewer to ask direct questions to specific areas of interest (Green et al., 2010) was the most appropriate option. Sample selection was driven by the following factors; (a) location and environment of the building (b) season in the year (c) age of building, and (d) evidence of dampness.

Households located in the Northern and southern parts of England were selected given their varying weather and environmental conditions (McMullan, 2017). For this study, household can be defined as groups of relatives or people living in the same housing unit, and dependent of each other by means of domestic or living rules (Francisco et al., 2007). The study was conducted in Autumn and Winter seasons in 2017 due to the higher contribution to dampness by households (Wang et al., 2016), but the questions covered other seasons as well for comparative analysis. The temperatures at the time of study for Northern England were between 10-13 degree Celsius whilst it was 11-15 degree Celsius in the South. Further, given that dampness has a correlation with the age of buildings (Norback et al. 2017), relatively new buildings (less than 10 years) and old buildings (55 years and above) were selected in each region. Following the above criteria, occupants in five households (representative of the sample) were interviewed in the study.

\section{Data Collection Method}

Face-to-face semi-structured interviews were carried out with occupants in households to identify actions influencing dampness and those carried out to reduce dampness, taking into consideration time, environment and random occurrences. In total, 15 in depth interviews were carried out across the households to examine the behaviours of occupants manifested to manage dampness.

The interview comprised of thirty (30) questions and lasted for an average of 65 minutes per person. Questions asked comprised demographic information (7 questions), evidence of dampness (5 main question with 11 sub questions) and behaviours for reducing dampness (10 questions), knowledge of the impact of dampness (5 questions) and behaviours affected by dampness (3 questions). Demographic question covered their gender, age, occupation, education, age of house, and whether they owned their houses. Under evidence of dampness-related questions, in addition to general diagnostic evidence of dampness such as moulds, moisture, water droplets, hygroscopic salts outlined by (Halim et al., 2012; Burkinshaw \& Parrett, 2004), questions on behavioural activities deduced from the study of Yang et al. 
(1997), were asked to identify occupant contribution to dampness. For example, use of a dehumidifier, use of natural plants indoors, pets, carpets, incense burning, frequency of cooking, and allergy to mould. Also, occupants showed the researcher the visual evidence of dampness in the building. Behaviours manifested whilst reducing dampness were sought, taking into consideration the time of the day, environment and random occurrences. Questions asked to identify behaviours manifested focused on dimensions of behaviours; actions, beliefs and attitudes (Ajzen 1985; Blaga, 2014) in reducing dampness. A summary of demographic information of the occupants from the five households is captured in Table 2. From Table 2, $1 \mathrm{~N}, 2 \mathrm{~N}$ and $3 \mathrm{~N}$ stand for houses 1,2 and 3 in the Northern part respectively whilst $1 \mathrm{~S}$ and $2 S$ stand for houses 1 and 2 in the Southern part of England respectively. Specifically, houses in the North; 1N, 2N and 3N were located in Durham, York and Manchester respectively whilst houses in the south; $1 \mathrm{~S}$ and 2S were located in London and Southampton respectively. Also, in Table 2, '01, 02, 03' are the unique codes provided for the occupants. For example, ' $1 \mathrm{~N}-01$ ' stands for house 1 in the north, occupant 1.

Table 2: Demographic information of occupants (respondents) in the Households

\begin{tabular}{|c|c|c|c|c|c|c|c|c|}
\hline Location & Respondent & Gender & $\begin{array}{l}\text { Age of } \\
\text { occupant }\end{array}$ & $\begin{array}{l}\text { Educational } \\
\text { qualification }\end{array}$ & $\begin{array}{l}\text { Occupation } \\
\text { of occupant }\end{array}$ & $\begin{array}{l}\text { Age of } \\
\text { house }\end{array}$ & $\begin{array}{l}\text { Owner of } \\
\text { the } \\
\text { house? }\end{array}$ & $\begin{array}{l}\text { Duration of } \\
\text { staying in } \\
\text { the house } \\
\text { (years) }\end{array}$ \\
\hline \multirow[t]{8}{*}{ Northern } & $1 \mathrm{~N}-01$ & Female & 26 & $\begin{array}{l}\text { Postgraduate } \\
\text { degree }\end{array}$ & Data manger & 55 & No & 1.8 \\
\hline & $1 \mathrm{~N}-02$ & Male & 38 & Doctorate & $\begin{array}{l}\text { Research } \\
\text { Assistant }\end{array}$ & 56 & No & 2 \\
\hline & $2 \mathrm{~N}-03$ & Female & 26 & A level & Care worker & 50 & No & 2 \\
\hline & $2 \mathrm{~N}-04$ & Male & 31 & $\begin{array}{l}\text { Postgraduate } \\
\text { degree }\end{array}$ & Logistic agent & 50 & No & 2 \\
\hline & $2 \mathrm{~N}-05$ & Male & 19 & A level & Student & 50 & No & 2 \\
\hline & $3 N-06$ & Male & 35 & $\begin{array}{l}\text { Postgraduate } \\
\text { degree }\end{array}$ & Pharmacist & 3 & Yes & 3 \\
\hline & $3 N-07$ & Female & 31 & Doctorate & Academic & 3 & No & 3 \\
\hline & $3 N-08$ & Female & 18 & GCSE & Student & 3 & No & 3 \\
\hline \multirow[t]{7}{*}{ Southern } & 1S-09 & Female & 28 & $\begin{array}{l}\text { Undergraduate } \\
\text { degree }\end{array}$ & Accountant & 50 & No & 3 \\
\hline & $1 S-10$ & Male & 30 & $\begin{array}{l}\text { Undergraduate } \\
\text { degree }\end{array}$ & Guitarist & 50 & No & 1.5 \\
\hline & $1 S-11$ & Female & 46 & GCSE & $\begin{array}{l}\text { Stay home } \\
\text { mother }\end{array}$ & 50 & No & 3 \\
\hline & $1 S-12$ & Female & 25 & $\begin{array}{l}\text { Undergraduate } \\
\text { degree }\end{array}$ & $\begin{array}{l}\text { Operations } \\
\text { manager }\end{array}$ & 50 & No & 3 \\
\hline & $1 S-13$ & Male & 27 & $\begin{array}{l}\text { Postgraduate } \\
\text { degree }\end{array}$ & $\begin{array}{l}\text { Personal } \\
\text { Banker }\end{array}$ & 50 & No & 1 \\
\hline & $2 S-14$ & Female & 29 & $\begin{array}{l}\text { Postgraduate } \\
\text { degree }\end{array}$ & Auditor & 2 & No & 1.5 \\
\hline & $2 S-15$ & Male & 40 & A level & $\begin{array}{l}\text { Security } \\
\text { Officer }\end{array}$ & 2 & No & 4 \\
\hline
\end{tabular}




\section{Analysis of results}

The results were analysed by coding to the themes from the questionnaire using Nvivo 11. After an iterative coding process, high level themes (nodes) such as; demographic information, role of occupants in contributing to dampness, psychological attitudes affected by dampness and behaviours to reduce dampness were identified.

Across, the households, all respondents were educated, and the background of respondents varied, ranging from professionals to stay-home parents and students. The average age of respondents in the northern part of England was 27 whilst the average age of those in the southern part was 32 . Out of the three houses studied in the north, one was a 3-bedroom semi-detached (3N) whilst two were 3-bedroom terraced houses $(1 \mathrm{~N}, 2 \mathrm{~N})$. In the south, one 3-bedroom terrace (1S) and one 3-bedroom semi-detached (2S) were studied. Occupants staying in relatively new and old houses were interviewed in both areas. For example, old houses both in the North and South were from 50 years whilst new houses in the North and South were 3 and 2 years respectively. Both occupants in the north and southern parts had stayed in the same house for an average of 2.4 years. Due to the relatively large working-class group of the respondents, the homes were generally used as resting and eating places.

From the results, all houses had evidence of dampness with the houses more than 50 years having more dampness. For all houses in the northern part of England, evidence of dampness as highlighted by occupants was the moulds in the house. The location of moulds in house $1 \mathrm{~N}$ and $3 \mathrm{~N}$ was the bathrooms and sitting rooms whilst for house $2 \mathrm{~N}$, it was in the kitchen. In the southern part, evidence of dampness in the house was moulds. The location of dampness for house 1S was the bedroom, kitchen and bathroom. For household 2S, evidence of dampness was in the bathroom and bedroom.

Within each household, respondents had varying views of the factors that caused dampness. Figure 2 captures the varying views of occupants even in the same building. These views were mainly 'activities carried out' and 'the time of the year' with the latter (at 65 percent) being the most common factor causing dampness. The activities comprised closing windows, bathing very warm water, having natural plants in doors, washing and cooking. Winter was the time of the year where respondents thought dampness increased. It was confirmed by all respondents that the location of the house and vegetation outside the house played little role in the dampness identified within the buildings. 


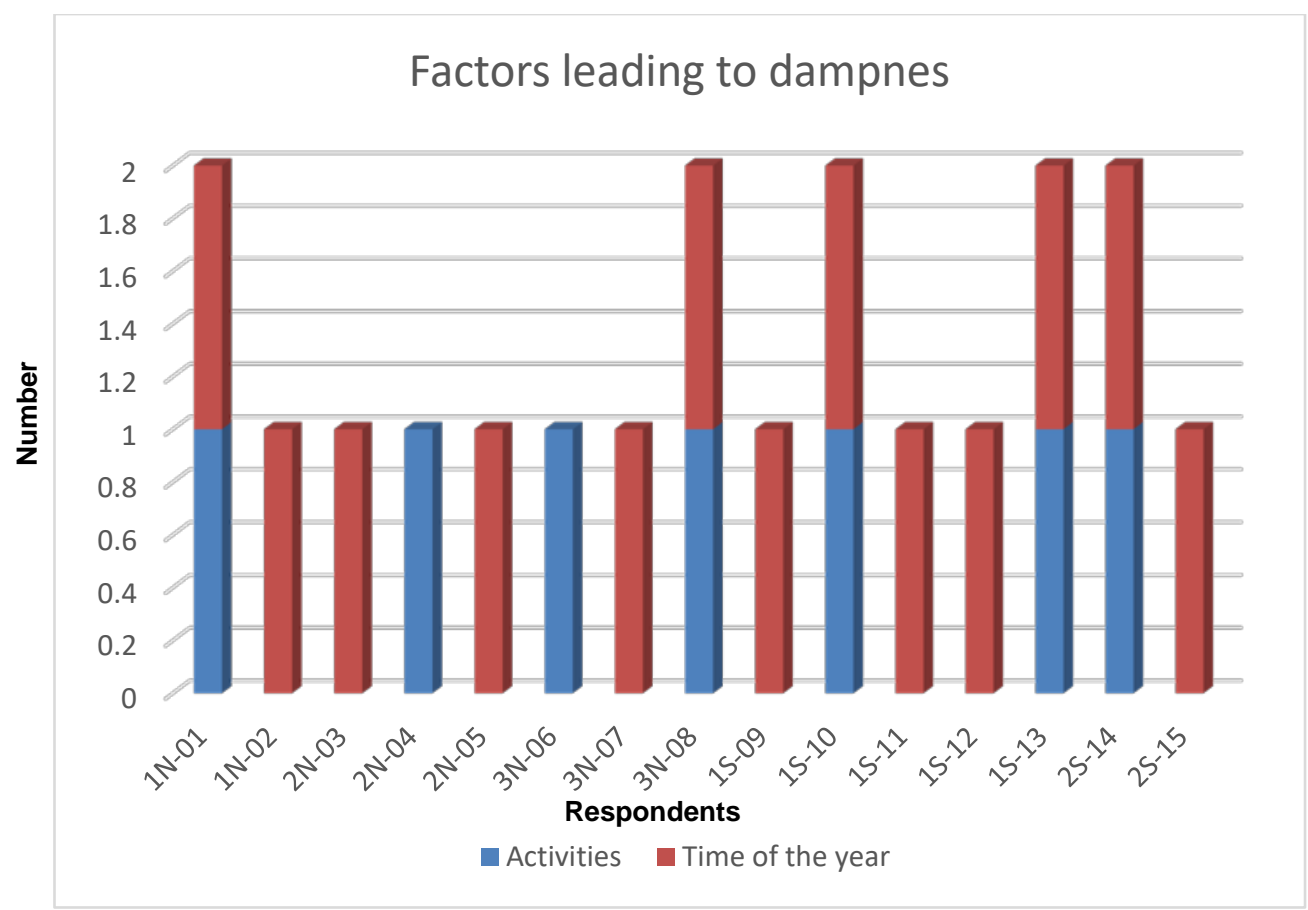

Figure 2: Factors leading to dampness

Following the identification of factors leading to dampness, the contributory behaviours to dampness varied. Respondents confirmed that they had contributed to dampness. In the northern part of England, examples of evidence of roles played are captured below:

'closing the windows, making the house too warm because of personal reaction to cold' (Respondent 1N-01);

'Bathing with very warm water which creates much steam and not opening the windows' (Respondent 2N-04);

'Having a lot of natural plants in the house' (Respondent 3N-06).

In the Southern part of England, examples of evidence of roles played include;

'I avoid opening windows because of the fear of cold' (Respondent 1S-10) and

'due to energy saving I do not open windows' (Respondent 2S-14).

Actions by the respondents to reduce dampness varied, with aeration and the use of anti-mould sprays being the common methods used. The duration of aeration varied from one household to the other with consciousness of energy bills and the fear of cold being the factor that limits the duration for aeration. Table 3 captures the various time allowed for aeration and anti-mould sprays and cleaners by 
respondents. The average time allowed for the building aerating is 3.55 hours in a day. Whilst it took the semi-detached buildings in the north and south an average of 3.4 hours, terraced houses in the north and south took 3.6 hours. Thus, the average hours to aerate the building was influenced by the building type not the location of the building.

Table 3: Durations of actions allowed for reducing dampness

\begin{tabular}{lll}
\hline Respondent & Action & Duration \\
\hline $1 \mathrm{~N}-01$ & Aerate & 4 hours \\
$1 \mathrm{~N}-02$ & Aerate & 8 hours \\
$2 \mathrm{~N}-03$ & Use of extractor & 0.25 hours \\
$2 \mathrm{~N}-04$ & Anti-mould spray & once a week \\
$2 \mathrm{~N}-05$ & Aerate & 1 hour \\
$3 \mathrm{~N}-06$ & Anti-mould spary & once a month \\
$3 \mathrm{~N}-07$ & Aerate & 8 hours \\
$3 \mathrm{~N}-08$ & Aerate & 3 hours \\
1S-09 & Aerate & 5 hours \\
1S-10 & Aerate & 0.17 hours \\
1S-11 & Anti-mould spray & twice a week \\
$1 \mathrm{~S}-12$ & Damp-cleaners & every other month \\
1S-13 & Anti-mould spray & once a week \\
$2 \mathrm{~S}-14$ & Aerate & 0.08 hours \\
$2 \mathrm{~S}-15$ & Aerate & 2.75 hours \\
\hline
\end{tabular}

Respondents in the North and South had similar views on the impact of aerating buildings. For example, respondents in the North $(1 \mathrm{~N}-01,1 \mathrm{~N}-02,2 \mathrm{~N}-05,3 \mathrm{~N}-07)$ and South, (1S-09, 1S-10, 2S-14, 2S-15) confirmed that aerating the buildings led to moisture reduction and mould prevention. Also, respondents shared other personal attitudes that had motivated dampness reduction as captured in Figure 3. Out of the attitudes shared, the main motivator for dampness reduction was the dislike of the sight of moulds.

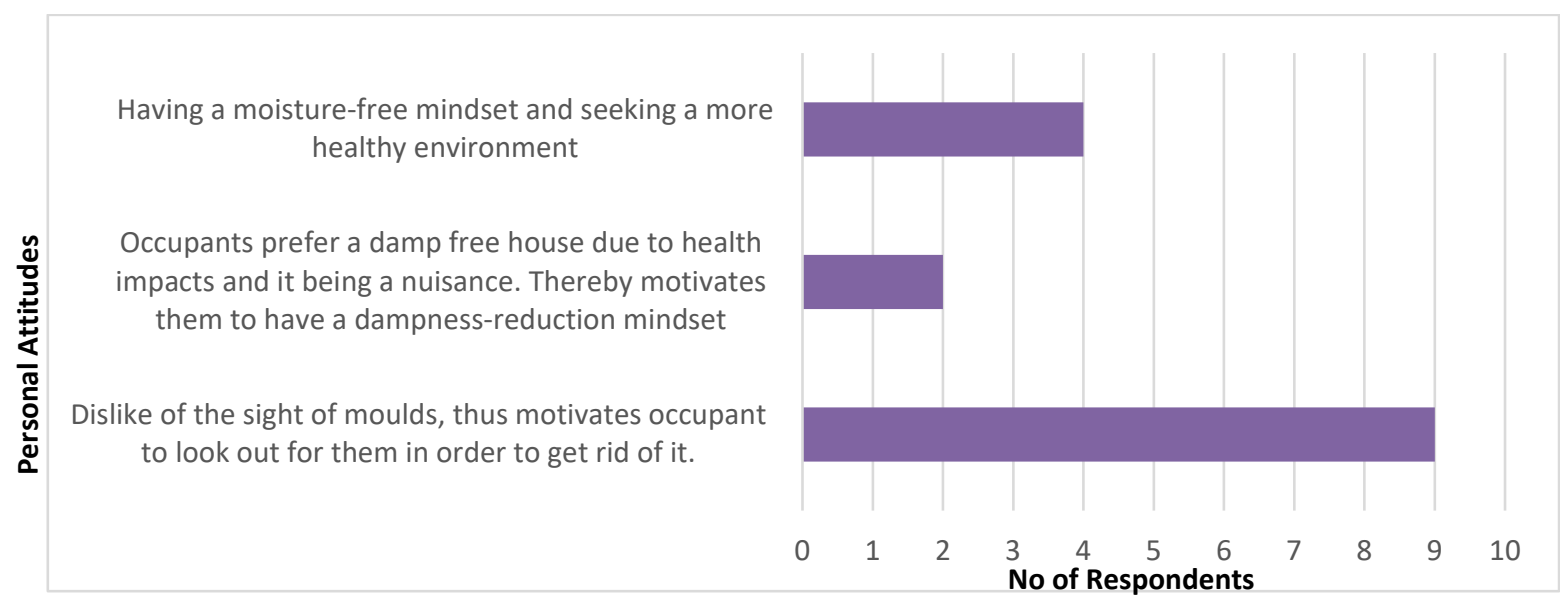

Figure 3: Personal attitudes motivating dampness reduction 
Respondents expressed their beliefs with dampness especially in terms of the impact on the health, namely fear of hazards dampness brings and it being a nuisance. For example, some occupants shared;

'I am scared of the hazards dampness brings that's why I rather open the windows upstairs all night' (Respondent 3N-07) and

'it's a nuisance and I think it is not good for the health' (Respondent 1S-09).

They concluded that, the health impact was more important to them than the structural instability dampness causes. As such, except for one respondent (3N-06) who owned the house, very little external help had been sought by respondents in reducing dampness in terms of the impact of the structure.

All respondents confirmed dampness had instilled some attitudes in them. The major negative attitude instilled in respondents is anger whilst the positive attitude instilled is cleaning. Other attitudes captured are outlined in Figure 4. The fights caused by dampness were due to the increase in energy bills as a result of opening windows and lack of understanding of the negative impact of dampness by some occupants. Further, the uncomfortable, cranky and angry attitudes were due to the visual, smell and health implication of dampness.

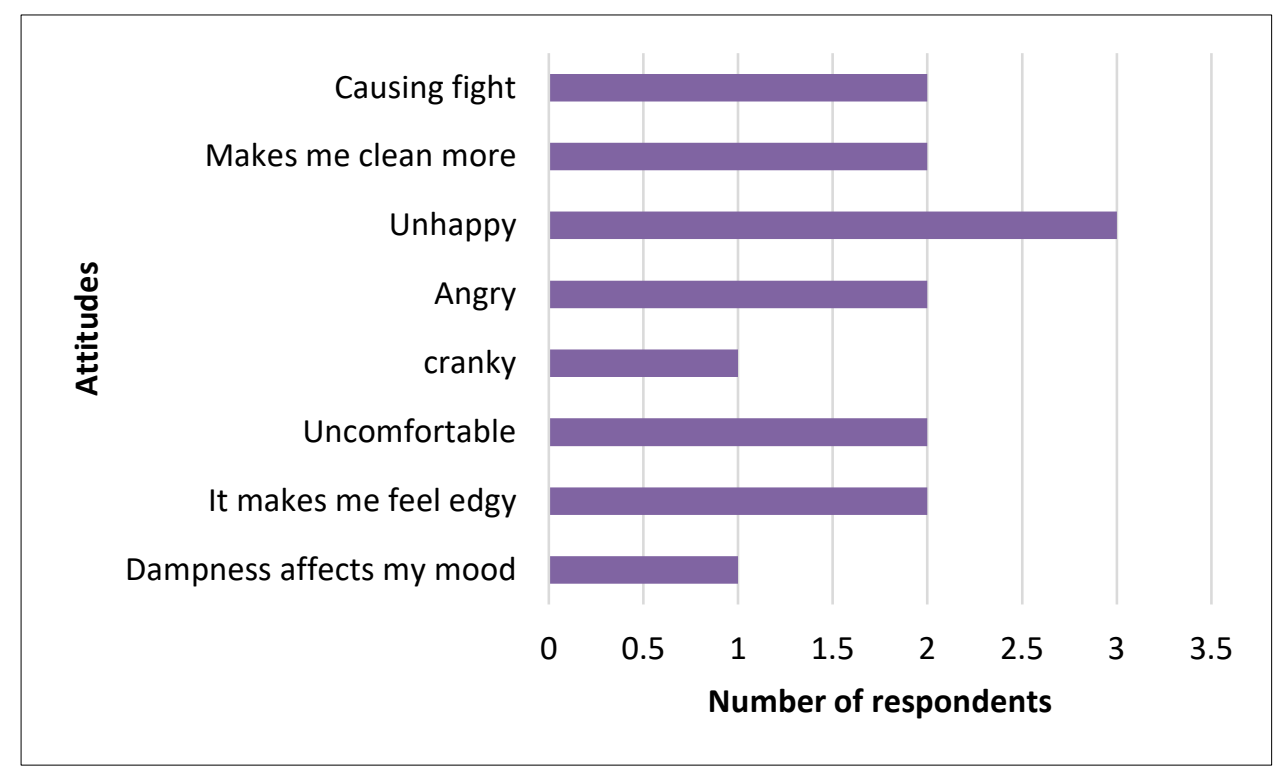

Figure 4: Attitudes instilled by dampness

Recommendations for reducing dampness from respondents were continuous aeration irrespective of the season, avoiding overcrowding and continual cleaning. 


\section{Discussion of Findings}

Findings show that activities carried out by occupants make up 35 percent of the factors which lead to dampness whilst the time of the year contributes 65 percent to dampness. These findings confirm Hunter et al. (1988) study on the main factors leading to dampness in England and questions why little research to observe behaviours and identify how dampness can be reduced by altering behaviours has received little focus. However, the behaviours identified from the study varied from Hunter et al. (1988) study and depicts the change in behaviours and the specific behaviours to be further studied to enhance dampness reduction. The roles identified from the study include closing windows, bathing very warm water and having natural plants in doors. These had similarities with Yilmaz et al. (2017) specifically with closing windows, and Yang et al. (1997) in having plants in doors. The behaviours in contributing to dampness has evolved from being influenced by cleaning the household (Hunter et al.,1988) to energy-efficiency conscious identified in the study. Based on this, it can be deduced that, priority is now given to energy efficiency instead of damp-free buildings without in depth consideration of the long-term impact of dampness (example health). Thus, confirming that people have now skewed to be short-term thinkers which are influenced by the scarcity of resources (Rappaport, 2005) and technological evolution (Nicholson, 2015).

The common actions to reduce dampness were aeration for an average 3.4 hours for semi-detached and 3.6 hours for terraced houses in addition to the use of damp and mould cleaners. Thus, semi-detached houses are relatively faster to aerate than terraced houses. The 3 to 4 hours aeration findings in this research concurs with that found by Wallace et al. (2002) in Virginia United States on the number of hours to aerate a town house. Despite the varying wind and temperature in Virginia and the northern and southern parts of England, the common factor is the number of rooms, thus it can be said that a 9-room house requires 3-4 hours of aeration. Also, the findings show specific behaviours for managing dampness after diagnosis and adds to the construction focussed methods (Burkinshaw \& Parrett, 2004) and external training and education (Bluyssen et al., 2010). Beliefs of dampness were mainly the fear of negative health impact and it being a nuisance. The beliefs motivated occupants to reduce dampness, as such can be said to be a driver of dampness reduction.

The behaviours instilled by dampness were more than the behaviours manifested to reduce dampness. Form this study, dampness affected occupants positively and negatively. Whilst the negative impact ranges from causing fights, to being unhappy, angry, cranky, uncomfortable, edgy and moody, the identified impact from literature has largely been health impact caused by air contamination (example Holst et al., 2016). Thus, not covering the psychological impacts of dampness on occupants and its impact to the wider society. As such, the findings from this research throws light on these psychological 
effects of dampness. Fights caused by dampness was due to misunderstandings by occupants with one preferring to save energy than reducing dampness and vice versa. These priority differences were caused as a result of lack of education on the impact of dampness on the building and its health impact and shortterm benefit of energy saving by occupants. Other psychological effects such as being unhappy, angry, cranky, lack of comfort, edgy and moody affects the productivity of the occupant and the relationship with other occupants and any third party. These psychological effects can be said to be caused by emotional instability dampness breeds as a result of air change and smell confirming a study on the impact of air quality on emotions by Lee et al. (2008) and physical instability as a result of visual moulds, peeling of paint, decolourisation of walls and insects' dampness breeds. On the other hand, dampness was identified to instil in occupants a cleaning habit. Thus, occupants confirming that, they would not have cleaned as much if there was no evidence of dampness. The findings from this study are summarised in Figure 5. 
Role of occupants in contributing to dampness

-Closing windows,

-Having natural plants in doors,
-Bathing very warm water,

- Washing and cooking

Psychological attitudes affected by dampness

\begin{tabular}{|lll|}
\hline -Causing fights & -Being unhappy, & -Angry, \\
- Cranky, & -Uncomfortable, & -Edgy and moody \\
\hline
\end{tabular}

Behaviours to reduce dampness

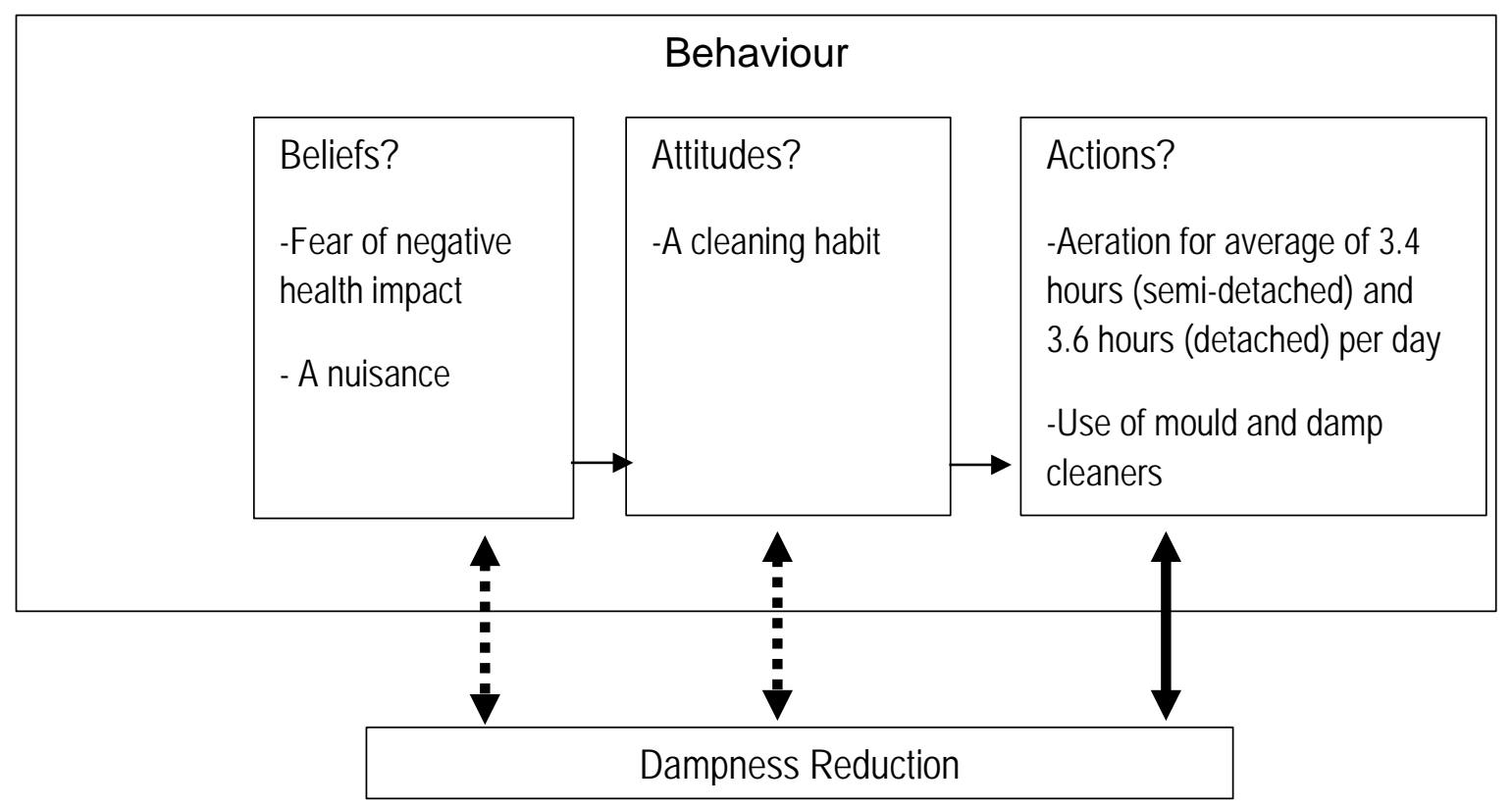

Figure 5: Developed framework for behaviours in dampness reduction 


\section{Conclusion}

To date, the consideration of behaviours affecting and affected by reactively reducing dampness has received little focus. This therefore challenges the success of dampness-reduction approaches given that the human factor plays a significant role. This research has therefore identified the behaviours affected by dampness and those required to reduce dampness in residential buildings. From the findings, energy reduction is relatively more important to occupants than dampness reduction. This shows the evolution of occupant priorities since its first study in residential buildings in the 1980's. Findings confirm that occupants continually contribute to dampness through the daily activities and this makes up about $35 \%$ of the factors leading to dampness. The identified roles occupants play in contributing to dampness include closing windows, bathing very warm water, having natural plants indoors and washing and cooking. These roles are similar to previous studies on occupant contribution to dampness. From this study, the novel finding is the psychological attitudes influenced by dampness namely fighting, crankiness, lack of comfort, unhappiness, anger and moodiness. These novel findings broaden the identification of the impact of dampness in addition to the health impact caused by air contamination. In addition, behaviours to reduce dampness, comprising beliefs such as; fear of negative health impact, and nuisance; attitudes such as, cleaning and; actions comprising aeration for an average of 3.55 hours a day and the use of mould and damp cleaners have also been identified. These behaviours identified are specific to occupants in residential buildings and may not be the same for commercial and other forms of buildings. As such, future work could focus on behaviours affecting and being affected by dampness in other forms of buildings. These findings identify the psychological niches where further research similar to air contamination on health impact can be explored.

\section{References}

Agyekum, K., Ayarkwa, J., \& Salgin, B. (2017). Diagnosing damp in a tropical building: Applying theory to practice. International Journal of Architecture, Engineering and Construction, 6(4), 44-50.

Agyekum, K., \& Ayarkwa, J. (2014). Dampness in Walls of Residential Buildings: The Views of Building Construction Professionals in Ghana. Africa Development and Resources Research Institute Journal, 7 (7),19-36.

Agyekum, K., Ayarkwa, J., Koranteng, C., \& Adinyira, E. (2013). Preliminary assessment of dampness in walls of residential buildings in four climatic zones in Ghana. Journal of Sustainable Development, 6(9), 51-61. 
Ajzen, I. (1985). From intentions to actions: A theory of planned behavior. Action control: From cognition to behavior. Edited by: Kuhl J, Beckmann J.

Ajzen, I., 2005. Attitudes, personality, and behavior. McGraw-Hill Education (UK).

Ahadzie, D.K., Proverbs, D.G. and Olomolaiye, P. (2008) "Towards developing competency-based measures for construction project managers: Should contextual behaviours be distinguished from task behaviours?" International Journal of Project Management, 26: 631-645.

Blaga, A. (2014). What is the difference between competencies and behaviours when establishing performance criteria? Individual performance. The KPI Institute

Bluyssen, P. M., de Richemont, S., Crump, D., Maupetit, F., Witterseh, T., \& Gajdos, P. (2010). Actions to reduce the impact of construction products on indoor air: outcomes of the European project HealthyAir. Indoor and Built Environment, 19(3), 327-339.

Boyatzis, R. E. (1982) The Competent Manager: A Model For Effective Performance. New York: John Wiley and Sons.

Burberry, P. (2014). Environment and services. Routledge.

Burkinshaw, R., \& Parrett, M. (2003). Diagnosing damp. RICS books.

Caupin, G. (2006) ICB: IPMA competence baseline; Version 3.0. Nijkerk, IPMA.

Eastman, C., Teicholz, P., Sacks, R., and Liston, K. (2011). BIM handbook: A guide to building information modeling for owners, managers, designers, engineers and contractors, Wiley, New York.

Fellows, R. \& Liu, A. (2008). Research Methods for Construction 3rd ed., Chichester: Blackwell publishing.

Fishbein, M., \& Ajzen, I. (2005). The influence of attitudes on behavior. The handbook of attitudes, 173222. 
Francisco, E., Aranha, F., Zambaldi, F., \& Goldszmidt, R. (2007). Electricity consumption as a predictor of household income: a spatial statistics approach. In Advances in geoinformatics (pp. 267-282). Springer, Berlin, Heidelberg.

Franzoni, E. (2014). Rising damp removal from historical masonries: A still open challenge. Construction and Building Materials, 54, 123-136.

Gelber, S. (1997) 'Do-lt-Yourself: Constructing, Repairing and Maintaining Domestic Masculinity', American Quarterly 49(1): 66-112

Heseltine, E., \& Rosen, J. (Eds.). (2009). WHO guidelines for indoor air quality: dampness and mould. WHO Regional Office Europe.

Holst, G. J., Høst, A., Doekes, G., Meyer, H. W., Madsen, A. M., Plesner, K. B., \& Sigsgaard, T. (2016). Allergy and respiratory health effects of dampness and dampness-related agents in schools and homes: a cross-sectional study in Danish pupils. Indoor air, 26(6), 880-891.

Hong, T., \& Lin, H. W. (2013). Occupant behavior: impact on energy use of private offices (No. LBNL6128E). Ernest Orlando Lawrence Berkeley National Laboratory, Berkeley, CA (US).

Hunter, C. A., Grant, C., Flannigan, B., \& Bravery, A. F. (1988). Mould in buildings: the air spora of domestic dwellings. International biodeterioration, 24(2), 81-101.

Huang, C., Liu, W., Cai, J., Wang, X., Zou, Z., \& Sun, C. (2017). Household formaldehyde exposure and its associations with dwelling characteristics, lifestyle behaviours, and childhood health outcomes in Shanghai, China. Building and Environment, 125, 143-152.

Keall, M. D., Crane, J., Baker, M. G., Wickens, K., Howden-Chapman, P., \& Cunningham, M. (2012). A measure for quantifying the impact of housing quality on respiratory health: a cross-sectional study. Environmental Health, 11(1), 33-40.

Klein, L., Kwak, J. Y., Kavulya, G., Jazizadeh, F., Becerik-Gerber, B., Varakantham, P., \& Tambe, M. (2012). Coordinating occupant behavior for building energy and comfort management using multi-agent systems. Automation in construction, 22, 525-536.

Lampel, J. (2001) "The core competencies of effective project execution: the challenge of diversity." International Journal of Project Management, 19: 471-483. 
Lee, Y. K., Lee, C. K., Lee, S. K., \& Babin, B. J. (2008). Festivalscapes and patrons' emotions, satisfaction, and loyalty. Journal of Business Research, 61(1), 56-64.

Mendell, M. J. (2017). A Research Agenda on Assessing and Remediating Home Dampness and Mould to Reduce Dampness-Related Health Effects.

McMullan, R. (2017). Environmental science in building. Palgrave Macmillan Education.

Mirabile, R. J. (1997) "Everything You Wanted to Know about Competency Modeling."

Training and Development, 51: 73-77.

Moon, H. J., \& Yoon, Y. R. (2010). Investigation of physical characteristics of houses and occupants' behavioural factors for mould infestation in residential buildings. Indoor and Built Environment, 19(1), 57-64.

Nicholson, S. (2015). A recipe for meaningful gamification. In Gamification in education and business (pp. 1-20). Springer, Cham.

Norbäck, D., Zock, J. P., Plana, E., Heinrich, J., Tischer, C., Jacobsen Bertelsen, R., ... \& Verlato, G. (2017). Building dampness and mould in European homes in relation to climate, building characteristics and socio-economic status: The European Community Respiratory Health Survey ECRHS II. Indoor air, 27(5), 921-932.

Peng, C., Yan, D., Wu, R., Wang, C., Zhou, X., \& Jiang, Y. (2012, June). Quantitative description and simulation of human behavior in residential buildings. In Building simulation 5, (2), 85-94. Tsinghua Press.

Rappaport, A. (2005). The economics of short-term performance obsession. Financial Analysts Journal, 61(3), 65-79.

Rirsch, E., \& Zhang, Z. (2010). Rising damp in masonry walls and the importance of mortar properties. Construction and Building Materials, 24(10), 1815-1820.

Rock, I. (2017). Common defects surveyors encounter in Victorian and Edwardian properties. Journal of Building Survey, Appraisal \& Valuation, 5(4), 320-331.

Skinner, B. F. (1953). Science and human behavior. Simon and Schuster.

Torres, M. I. M., \& de Freitas, V. P. (2007). Treatment of rising damp in historical buildings: wall base ventilation. Building and environment, 42(1), 424-435. 
Ulrich, D., Brockbank, W., Yeung, A. K., \& Lake, D. G. (1995). Human resource competencies: An empirical assessment. Human Resource Management, 34, 473-495.

Wallace, L. A., Emmerich, S. J., \& Howard-Reed, C. (2002). Continuous measurements of air change rates in an occupied house for 1 year: the effect of temperature, wind, fans, and windows. Journal of Exposure Science and Environmental Epidemiology, 12(4), 296.

Wang, X., Liu, W., Huang, C., Cai, J., Shen, L., Zou, Z., ... \& Zhao, Z. (2016). Associations of dwelling characteristics, home dampness, and lifestyle behaviors with indoor airborne culturable fungi: On-site inspection in 454 Shanghai residences. Building and Environment, 102, 159-166.

Watson M., Shove E. (2008). Product, Competence, Project and Practice. Journal of Consumer Culture, 8(1), 69-89.

Yang, C. Y., Chiu, J. F., Chiu, H. F., \& Kao, W. Y. (1997). Damp housing conditions and respiratory symptoms in primary school children. Pediatric pulmonology, 24(2), 73-77.

Yilmaz, S., Firth, S. K., \& Allinson, D. (2017). Occupant behaviour modelling in domestic buildings: the case of household electrical appliances. Journal of Building Performance Simulation, 10(5-6), 582-600 